\title{
Model of Student Character Based on Character Building in Teaching Learning Process
}

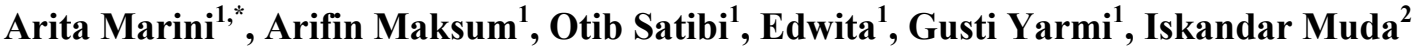 \\ ${ }^{1}$ Department of Elementary School Teacher Education, Universitas Negeri Jakarta, Indonesia \\ ${ }^{2}$ Department of Accounting, Universitas Sumatera Utara, Indonesia
}

Received August 4, 2019; Revised August 26, 2019; Accepted September 12, 2019

Copyright $(2019$ by authors, all rights reserved. Authors agree that this article remains permanently open access under the terms of the Creative Commons Attribution License 4.0 International License

\begin{abstract}
The aim of this research is to offer a model for student character on the basis of character building in teaching learning process. The sample group with 450 students represented grades 4-6 from 5 elementary schools in Jakarta. The Structural Equation Modeling (SEM) was used to analyse the data of this research. The findings confirmed that character building in teaching learning process encouraging student character was not supported. Preparation of teaching learning process, the core of teaching learning process, and the closing of teaching learning process supported character building in teaching learning process. The student love of learning and the student perseverance predicting student character were not supported in this research. The student prudence supported the student character. SEM measurement showed that the model promoted in this study is a fit model. This study gives a practical contribution by showing that character building in teaching learning process can improve the level of student noble characters by supplying a model for student character. Using this model, the students' positive characters can be improved to prevent student moral decline. This study can address the students' positive attitudes through the model of study results.
\end{abstract}

Keywords Student Character, Character Building in Teaching Learning Process, Love of Learning, Perseverance, Prudence

\section{Introduction}

The condition of globalization era influences demands that Indonesia should be adapted selectively based its Pancasila ideology. National curriculum for elementary schools in Indonesia from the [1] has a priority on the developmental equity of spiritual, social, affective, cognitive, and psychomotor aspects of education. However, most of elementary schools generally pay attention on the cognitive aspect of education. Educational success of elementary schools is measured not only by cognitive aspects but also attitudinal aspects. Elementary schools in Indonesia have to serve as the foundation for student personality formation concerning student character. Jakarta as the capital city of Indonesia is very critical related to diminishing student moral quality in the globalization era. Elementary school age is a critical age to shape student personal character. Failure of moral cultivation for elementary school students will cause bigger problems in the future.

Character building can be implemented through culture, rules, regulations, events and ceremonies to give supportive examples of good habits for students [2]. Character building implemented has a positive association on student character, and character building could be very essential in teacher preparation during the accreditation process [3]. However, most research done have examined character building programs in general. This research focused on character building in teaching learning process and its impacts on student character.

According to [4] National recapitulation during the 2017/2018 academic years from the Ministry of Education and Culture on 10 May 2018 stated that 148,856 elementary schools, $1,480,710$ teachers, 25,395,436 students, 117,314 educational staff, and 1,114,408 learning groups were present in Indonesia. In addition to this, there were 1,537 state and 914 private elementary schools, 10,747 male and 27,903 female teachers, 420,539 male and 392,327 female students, 2,130 male and 1,536 female educational staff, and 29,116 learning groups in Jakarta in Indonesia. Additionally, there were 176 states and 197 private elementary schools in the north Jakarta region, 352 states and 179 private elementary schools in the south Jakarta region, 445 states and 197 private elementary schools in the east Jakarta region, 360 states and 241 private elementary schools in the west Jakarta region, and 
190 states and 100 private elementary schools in the central Jakarta region.

Student character has been assessed using graduate competency and evaluation standards. In the graduate competency standards, character evaluation is linked to the students' obedience to social regulation, nationalism, cleanliness and healthy habits, obedience to the teachings of religion, respects for others, and teamwork. In fact, evaluation of school quality is not optimal to evaluate student character. Therefore, elementary school evaluation is primarily on the basis of the reported documents. In fact, character values have not been integrated optimally in teaching learning process at elementary schools in Jakarta in Indonesia.

This research was done at 5 different elementary schools in the north, south, central, west, and east Jakarta regions and composed of Kelapa Gading Timur 03 state elementary school in the north Jakarta region, Tebet Timur 15 Pagi state elementary school in the south Jakarta region, Muhammadiyah 24 private elementary school in the east Jakarta region, Pinangsia 06 Pagi state elementary school in the west Jakarta region, and Karisma Islamic elementary school in central Jakarta. The survey was done at state, private, and Islamic elementary schools to get a whole description of elementary schools in Jakarta in Indonesia.

The accreditation of the Kelapa Gading Timur 03 state elementary school in the north Jakarta region is excellent, with 26 teachers, 293 male and 318 female students, 21 learning groups, curriculum 2013, and Internet access. The Tebet Timur 15 Pagi state elementary school in the south Jakarta region has not got accreditation and has 14 teachers, 130 male and 122 female students, 8 learning groups, curriculum 2013, and Internet access. The Muhammadiyah 24 private elementary school in the north Jakarta region has not got accreditation and has 10 teachers, 120 male and 98 female students, 6 learning groups, curriculum 2013, and no Internet access. The Pinangsia 06 Pagi state elementary school in the west Jakarta region has not got accreditation and has 8 teachers, 113 male and 99 female students, 6 learning groups, the KTSP curriculum, and Internet access. The Karisma Islamic elementary school in central Jakarta has not got accreditation and has 8 teachers, 113 male and 99 female students, 6 learning groups, the curriculum at school level, and Internet access.

\section{Literature Review}

Activities of character education have positive association with student self-esteem [5]. Through these activities, the students learn about emotional and social skills leading to improve their communication and interaction skills. However, these studies didn't give more detail explanation about how to measure the student positive behavior.

[2] stated that implementing character education at Pondok Pesantren Darunnajah (a religious institution) was dependent on knowledge, conditional methods, and practices. Educating character in terms of knowledge was applied through the formal subjects of akhlaq content, Islamic theology, Qur'an, Hadith, Fiqh, Mahfuzhat, Muthala'ah, and Ushuluddin. Those subjects taught the students about good characters. The conditional method was used to educate characters through role models from the Kyai, teachers, staffs, rules, and regulations at Pondok Pesantren. Character education was implemented through Ibadah practices or the practical duties of Islam.

[3] found that character building did not receive a high priority in the teacher education curriculum. Their study stated that character building was part of the mission in most private institutions but not in public institutions. However, [6] reported that character building was provided in the curricula and was an element of the school mission statements realized in school culture in a Catholic school, a Quaker school and a public school. [7] stated that hidden curricula through social and cultural activities enhanced the character education process, especially for the quality of interpersonal communication between students, including respect, equality, helpfulness, trust, and honesty.

[8] stated that character building through school culture included caring, cleanliness, beauty and tidiness, religious service obedience, conformity to the rules, mutual respect, politeness, family-like relationships, honesty and responsibility, togetherness, tidy document filing and educational infrastructure, and stakeholders' participation and involvement. [9] suggested that character building was implemented in the classroom, school culture, and extracurricular activities including Pramuka. Character was included in teaching learning process as a part of the lessons. Integration of character values was done through activities including lining up before entering the classroom, greeting and kissing the hand of the teacher and older people, behaving, and dressing modestly. Character values integrated in the Pramuka include mutual cooperation, mutual respect, discipline, helpfulness, honesty, responsibility, confidence, tolerance, perseverance, peacefulness, unity, and religiousness.

\section{Theoretical Framework}

This study hypothesizes that character building in teaching learning process predicts student character. The preparation, core, and closing of teaching learning process will predict the effectiveness of character building in teaching learning process [10]. The quality of student character will be predicted by the student love of learning, perseverance, and prudence [11]. Figure 1 shows the theoretical framework of this study. 


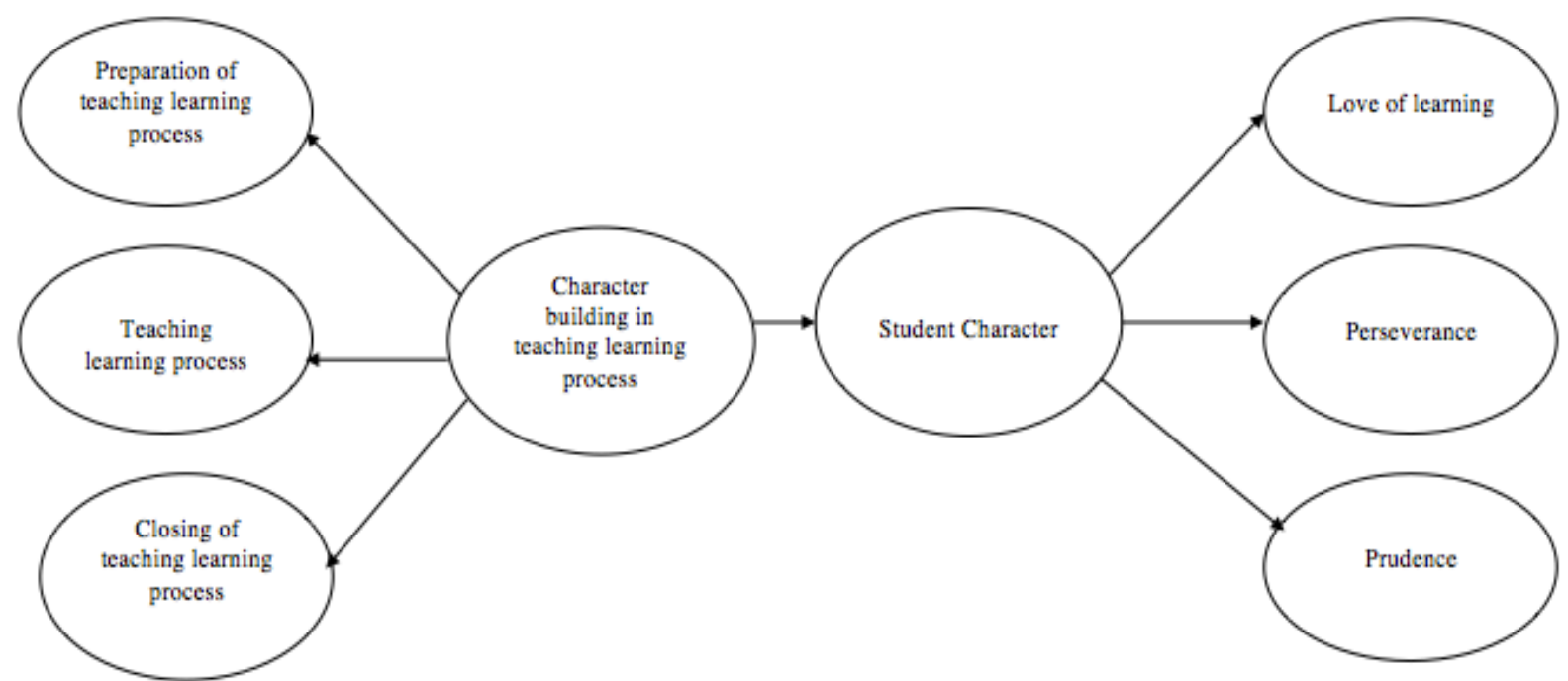

Figure 1. Theoretical framework of the study

\section{Materials and Methods}

A questionnaire survey was conducted to collect data related to character building in teaching learning process as the exogenous variable and student character as the endogenous variable in this study. A total of 450 elementary school students at 5 different elementary schools distributed in north, south, central, west, and east Jakarta in Jakarta in Indonesia responded to the survey.

In validating items for each study variable, the researcher applied content analysis of the literature for character building in teaching learning process based on [10], which consisted of preparation, core, and closing of teaching learning process, and student character based on [11], which had three dimensions of student love of learning, perseverance, and prudence. These ideals were converted into statements in the questionnaire distributed to 450 students.

The questions regarding character building in teaching learning process consisted of three dimensions: preparation of teaching learning process, the core of teaching learning process, and the closing of teaching learning process. Preparation of teaching learning process dimension consists of three indicators including the teacher asking the students to pray before starting the activities in class, the teacher connecting teaching material with developing positive attitude, and the teacher inspecting the neatness of student uniform. The core of teaching learning process dimension consists of three indicators involving the teacher applying the cooperative learning method in group-assignments, the teacher motivating the students to ask bravely, and the teacher paying attention to student attitude in class. The closing of teaching learning process dimension consists of three indicators involving the teacher asking the students to pray at the end of the class, the teacher asking the students to greet with the teacher at the end of the class, and the teacher asking the students to do reflection by integrating with character values at the end of the class.

The questions linked to student character composed of the following three aspects including the student love of learning, perseverance, and prudence. The student love of learning consists of four indicators involving the students doing the homework given by the teacher, the students doing the assignments given by the teacher, the students listening to the teacher explanation, and the students asking the teacher about the lesson not understood.

The student perseverance dimension consists of four indicators involving the students finishing the difficult assignment, the students learning because of being asked to do it is positively, the students finishing the homework given by the teacher, and the students being diligent to study. The student prudence dimension consists of four indicators involving the students forcing other students to receive their opinions, the students being happy to learn from other students, the students thinking thoroughly before doing something, and the students being not easy to trust other students.

The Structural Equation Modeling (SEM) analysis using IBM SPSS Statistics 24 and SPSS AMOS 24 with 2017 Edition was used to find out the set of association between character building in teaching learning process as the exogenous variable and student character as the endogenous variable. Data input was performed using Excel by entering the scores of each item on the basis of the responses of the 450 elementary school students in Jakarta in Indonesia with strongly agree, agree, neutral, disagree, and strongly disagree scored $5,4,3,2$, and 1, respectively, for positive questions and 1,2,3,4, and 5, respectively, for negative questions. 
Table 1. Model Fit Summary

\begin{tabular}{|c|c|c|c|}
\hline \multirow{2}{*}{ Fit measurement } & \multicolumn{3}{|c|}{ Fit Value } \\
\hline & Cut-Off Limitation & Value & Decision \\
\hline NFI & $0<\mathrm{NFI}<1 ; \mathrm{NFI} \geq 0.90=\operatorname{good}$ fit & 0.824 & Good Fit \\
\hline CFI & $0<\mathrm{CFI}<1 ; \mathrm{CFI} \geq 0.90=$ good fit & 0.876 & Good Fit \\
\hline IFI & $0<\mathrm{IFI}<1 ;$ IFI $\geq 0.90=$ good fit & 0.877 & Good Fit \\
\hline RFI & $0<$ RFI $<1 ;$ RFI $\geq 0.90=$ good fit & 0.797 & Good Fit \\
\hline GFI & $0<$ GFI $<1 ;$ GFI $\geq 0.90=$ good fit & 0.897 & Good Fit \\
\hline AGFI & $0<$ AGFI $<1 ;$ AGFI $\geq 0.90=$ good fit & 0.869 & Good Fit \\
\hline
\end{tabular}

Sources: AMOS Result (2019).

\section{Result and Discussion}

\subsection{Result}

The results of goodness-of-fit statistical analysis can be seen in Table I. These results showed that Normed Fit Index (NFI) value reached 0.824 indicating that the model offered in this research is good fit. The value of Comparative Fit Index (CFI) reached 0.876 showing that the model suggested is good fit. Incremental Fit Index (IFI) value reached 0.877 showing that the model is good fit. Relative Fit Index (RFI) value attained 0.797 showing that this model is good fit. Goodness of Fit Index (GFI) value reached 0.897 pointing out that the model is good fit. Adjusted Goodness of Fit Index (AGFI) value attained 0.869 suggesting that the model hypothesized is good fit. SEM measurement showed that model promoted in this study is a fit model.

A measurement model test of the observed variables is shown in Table 2 and 3. Table 2 and 3 showed that the observed variables preparation of teaching learning process, the core of teaching learning process, and the closing of teaching learning process had correlation coefficients with character building in teaching learning process of 0.931 , 1.034 , and 0.909 , respectively, which were significant at the 0.05 level based on the $t$ statistics. The observed variables consisting of the teacher asking the students to pray before starting the activities in class, the teacher connecting teaching material with developing positive attitude, the teacher inspecting the neatness of student uniform and preparation of teaching learning process had coefficients of $0.235,0.406$, and 0.917 , respectively, which were significant at the 0.05 level based on the $t$ statistics. The teacher applying the cooperative learning method in group assignments, the teacher motivating the students to ask bravely, the teacher paying attention to student attitude in class, and the core of teaching learning process had coefficients of $0.462,0.779$, and 0.908 , respectively, which were significant at the 0.05 level according to the $t$ statistics. The teacher asking the students to pray at the end of the class, the teacher asking the students to greet with the teacher at the end of the class, the teacher asking the students to do reflection by integrating with character values at the end of the class, and the closing of teaching learning process had significant positive association of $0.408,0.306$, and 1.011 .

Table 2 and 3 shows that the student love of learning and the student perseverance were correlated with student character of 0.855 and 1.061 , which were not significant at the 0.05 level based on the $t$ statistics. However, the student prudence was correlated with student character 0.696, respectively, which were significant at the 0.05 level based on the $t$ statistics. The students doing the homework given by the teacher, the students doing the assignments given by the teacher, the students listening to the teacher explanation, and the students asking the teacher about the lesson not understood had a relationship with the student love of learning with significant correlation coefficients of 0.787 , $0.709,0.461$, and 0.175 , respectively, at the 0.05 significance level. The students finishing the difficult assignment, the students learning because of being asked to do it, the students finishing the homework given by the teacher, and the students being diligent to study had positive correlations with the student perseverance with significant coefficients of $0.271,0.285,0.713$, and 0.544 , respectively. The students forcing other students to receive their opinions were positively associated with the student prudence, with significant coefficients of 0.098 . However, the students being happy to learn from other students, the students thinking thoroughly before doing something, and the students being not easy to trust other students were positively associated with the student prudence, but with no significant coefficients $-0.020,0.578$, and 0.086 , respectively, at the 0.05 significance level. The structural model test in Table 2 and 3 shows a direct effect of character building in teaching learning process on student character with a coefficient of 0.128 , which is not significant at the 0.05 levels. The structural model is shown in Figure 2.

The structural model test in Table 2 and 3 shows character building in teaching learning process had insignificant positive association with student character of 0.128 . This finding is not similar to that of the study of [12], which claimed that character building in teaching learning process promoted the student character. 
Table 2. Measurement model test (Regression Weights: Group number 1 - Default model)

\begin{tabular}{|c|c|c|c|c|c|c|c|}
\hline & & & Estimate & S.E. & C.R. & $\mathrm{P}$ & Label \\
\hline CHAR & $<---$ & TEACH & 0.010 & 0.008 & 1.183 & 0.237 & Not Valid \\
\hline PREP & $<---$ & TEACH & 0.801 & 0.029 & 27.430 & $* * *$ & \\
\hline CORE & $<---$ & TEACH & 0.815 & 0.025 & 32.814 & $* * *$ & \\
\hline CLOS & $<---$ & TEACH & 1.000 & & & & \\
\hline LEARN & $<---$ & CHAR & 5.649 & 4.151 & 1.361 & 0.174 & Not Valid \\
\hline PERSV & $<---$ & CHAR & 4.135 & 3.141 & 1.316 & 0.188 & Not Valid \\
\hline PRUD & $<---$ & CHAR & 1.000 & & & & \\
\hline $\mathrm{CB} 3$ & $<---$ & PREP & 1.000 & & & & \\
\hline $\mathrm{CB} 2$ & $<---$ & PREP & 0.325 & 0.038 & 8.473 & $* * *$ & \\
\hline $\mathrm{CB} 1$ & $<---$ & PREP & 0.152 & 0.032 & 4.801 & $* * *$ & \\
\hline CB6 & $<---$ & CORE & 1.000 & & & & \\
\hline CB5 & $<---$ & CORE & 1.266 & 0.057 & 22.292 & $* * *$ & \\
\hline CB4 & $<---$ & CORE & 0.415 & 0.039 & 10.538 & $* * *$ & \\
\hline CB9 & $<---$ & CLOS & 1.000 & & & & \\
\hline CB8 & $<---$ & CLOS & 0.231 & 0.035 & 6.572 & $* * *$ & \\
\hline CB7 & $<---$ & CLOS & 0.256 & 0.029 & 8.761 & $* * *$ & \\
\hline $\mathrm{SC} 1$ & $<---$ & LEARN & 1.000 & & & & \\
\hline $\mathrm{SC} 2$ & $<---$ & LEARN & 0.940 & 0.073 & 12.805 & $* * *$ & \\
\hline $\mathrm{SC} 3$ & $<---$ & LEARN & 0.689 & 0.079 & 8.699 & $* * *$ & \\
\hline $\mathrm{SC} 4$ & $<---$ & LEARN & 0.882 & 0.266 & 3.311 & $* * *$ & \\
\hline SC5 & $<---$ & PERSV & 1.000 & & & & \\
\hline SC6 & $<---$ & PERSV & 1.282 & 0.337 & 3.802 & $* * *$ & \\
\hline $\mathrm{SC} 7$ & $<---$ & PERSV & 1.938 & 0.388 & 4.995 & $* * *$ & \\
\hline SC8 & $<---$ & PERSV & 1.914 & 0.400 & 4.786 & $* * *$ & \\
\hline SC9 & $<---$ & PRUD & 1.000 & & & & \\
\hline $\mathrm{SC} 10$ & $<---$ & PRUD & -0.223 & 0.738 & -0.302 & 0.763 & Not Valid \\
\hline $\mathrm{SC} 11$ & $<---$ & PRUD & 4.927 & 3.632 & 1.357 & 0.175 & Not Valid \\
\hline $\mathrm{SC} 12$ & $<---$ & PRUD & 1.027 & 1.030 & 0.997 & 0.319 & Not Valid \\
\hline
\end{tabular}

Sources: AMOS Result (2019).

Table 3. Measurement model test (Standardized Regression Weights: (Group number 1 - Default model)

\begin{tabular}{|c|c|c|c|}
\hline & & & Estimate \\
\hline CHAR & $<---$ & TEACH & 0.128 \\
\hline PREP & $<---$ & TEACH & 0.931 \\
\hline CORE & $<---$ & TEACH & 1.034 \\
\hline CLOS & $<---$ & TEACH & 0.909 \\
\hline LEARN & $<---$ & CHAR & 0.855 \\
\hline PERSV & $<--$ & CHAR & 1.061 \\
\hline PRUD & $<---$ & CHAR & 0.696 \\
\hline CB3 & $<---$ & PREP & 0.917 \\
\hline CB2 & $<---$ & PREP & 0.406 \\
\hline CB1 & $<--$ & PREP & 0.235 \\
\hline
\end{tabular}




\begin{tabular}{|c|c|c|c|}
\hline & & & Estimate \\
\hline CB6 & $<--$ & CORE & 0.908 \\
\hline CB5 & $<---$ & CORE & 0.779 \\
\hline CB4 & $<--$ & CORE & 0.462 \\
\hline CB9 & $<--$ & CLOS & 1.011 \\
\hline CB8 & $<--$ & CLOS & 0.306 \\
\hline CB7 & $<---$ & CLOS & 0.408 \\
\hline SC1 & $<--$ & LEARN & 0.787 \\
\hline SC2 & $<--$ & LEARN & 0.709 \\
\hline SC3 & $<--$ & LEARN & 0.461 \\
\hline SC4 & $<--$ & LEARN & 0.175 \\
\hline SC5 & $<--$ & PERSV & 0.271 \\
\hline SC6 & $<--$ & PERSV & 0.285 \\
\hline SC7 & $<--$ & PERSV & 0.713 \\
\hline SC8 & $<---$ & PERSV & 0.544 \\
\hline SC9 & $<--$ & PRUD & 0.098 \\
\hline SC10 & $<--$ & PRUD & -0.020 \\
\hline SC11 & $<--$ & PRUD & 0.578 \\
\hline SC12 & $<--$ & PRUD & 0.086 \\
\hline SOS & & & \\
\hline
\end{tabular}

Sources: AMOS Result (2019).

Notes:

$\mathrm{CHAR}=$ student character

$\mathrm{TEACH}=$ character building in teaching learning process

$\mathrm{PREP}=$ preparation of teaching learning process

$\mathrm{CORE}=$ the core of teaching learning process

$\mathrm{CLOS}=$ the closing of teaching learning process

LEARN= love of learning

PERSV $=$ perseverance

$\mathrm{PRUD}=$ prudence

$\mathrm{CB} 1=$ the teacher asks the students to pray before starting the activities in class

$\mathrm{CB} 2=$ the teacher connects teaching material with developing positive attitude

$\mathrm{CB} 3=$ the teacher inspects the neatness of student uniform

$\mathrm{CB} 4=$ the teacher applies the cooperative learning method in group assignments

$\mathrm{CB} 5=$ the teacher motivates the students to ask bravely

$\mathrm{CB} 6=$ the teacher pays attention to student attitude in class

$\mathrm{CB} 7=$ the teacher asks the students to pray at the end of the class

$\mathrm{CB} 8=$ the teacher asks the students to greet with the teacher at the end of the class

$\mathrm{CB} 9=$ the teacher asks the students to do reflection by integrating with character values at the end of the class

$\mathrm{SC} 1=$ the students do the homework given by the teacher

$\mathrm{SC} 2=$ the students do the assignments given by the teacher

$\mathrm{SC} 3=$ the students listen to the teacher explanation

$\mathrm{SC} 4=$ the students ask the teacher about the lesson not understood

$\mathrm{SC} 5=$ the students finish the difficult assignment

SC6 $=$ the students learn because of being asked to do it

$\mathrm{SC} 7=$ the students finish the homework given by the teacher

SC8=the students are diligent to study

$\mathrm{SC} 9=$ the students force other students to receive their opinion

$\mathrm{SC} 10=$ the students are happy to learn from other students

SC11= the students think thoroughly before doing something

$\mathrm{SC} 12=$ the students are not easy to trust other students 


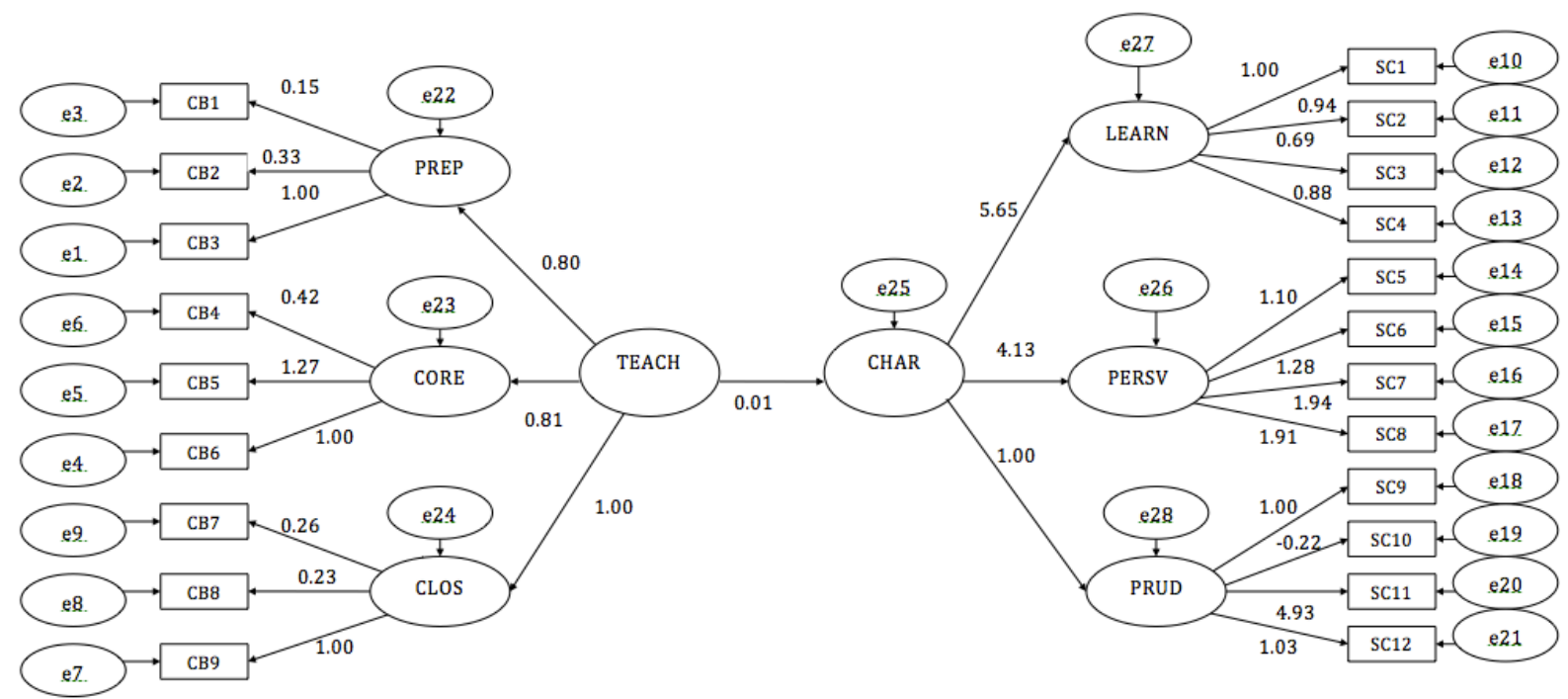

Sources: AMOS Result (2019).

Figure 2. The structural model

Based on Figure 2 show that the student love of learning and the student perseverance predicting student character were not supported in this research. The student prudence supported the student character. The students doing the homework given by the teacher, the students doing the assignments given by the teacher, the students listening to the teacher explanation, and the students asking the teacher about the lesson not understood predicted the student love of learning. The students finishing the difficult assignment, the students learning because of being asked to do it, the students finishing the homework given by the teacher, and the students being diligent to study supported the student perseverance. The students forcing other students to receive their opinions encouraged the student prudence. The students being happy to learn from other students, the students thinking thoroughly before doing something, and the students being not easy to trust other students predicting the student prudence were not supported in this research.

\subsection{Discussions}

Table 1 shows that the NFI value reached 0.824 , which was between 0 and 1 indicated that the model was fit. It can be seen in Table 1 that CFI value attained 0.876 , which was between 0 and 1 showing that the model proposes was fit. Table 1 also showed that the IFI was 0.877 , which was between 0 and 1 pointing out that the model offered is fit. It was shown in Table 1 that RFI reached 0.797, which was between 0 and 1 indicating that the model was fit. In Table 1, it can be seen that GFI attained 0.897 indicating that the model suggested was fit. The AGFI was 0.869 , which was between 0 and 1 pointing out that the model was fit. Based on the goodness-of-fit statistical analysis, it can be shown that the hypothesized model in this research was a good fit for the data.
Preparation of teaching learning process, the core of teaching learning process, and the closing of teaching learning process had significant association with character building in teaching learning process of $0.931,1.034$, and 0.909 , respectively. The teacher asking the student to pray before starting the activities in class, the teacher connecting teaching material with developing positive attitude, the teacher inspecting the neatness of student uniform and preparation of teaching learning process had significant connection of $0.235,0.406$, and 0.917 , respectively. The teacher applying the cooperative learning method in group assignments, the teacher motivating the students to ask bravely, the teacher paying attention to student attitude in class, and the core of teaching learning process had significant relationship of $0.462,0.779$, and 0.908 , respectively. The teacher asking the students to pray at the end of the class, the teacher asking the students to greet with the teacher at the end of the class, the teacher asking the students to do reflection by integrating with character values at the end of the class, and the closing of teaching learning process had significant positive association of $0.408,0.306$, and 1.011 . In line with the study of [10] and [13], character building in teaching learning process was related to preliminary activities, core activities, and closing teaching learning process.

Table 2 and 3 showed that the student love of learning and the student perseverance had insignificant positive association with student character of 0.855 and 1.061 . However, the student prudence had significant positive correlation with student character of 0.696 . The students doing the homework given by the teacher, the students doing the assignments given by the teacher, the students listening to the teacher explanation, and the students asking the teacher about the lesson not understood had positive significant relationship with the student love of learning of $0.787,0.709,0.461$, and 0.175 , respectively. The students 
finishing the difficult assignment, the students learning because of being asked to do it is positively, the students finishing the homework given by the teacher, and the students being diligent to study had significant positive correlations with the student perseverance of $0.271,0.285$, 0.713 , and 0.544 , respectively. The students forcing other students to receive their opinions had significant positive association with the student prudence of 0.098 . However, The students being happy to learn from other students, the students thinking thoroughly before doing something, and the students being not easy to trust other students had insignificant positive association with the student prudence of $-0.020,0.578$, and 0.086 , respectively. This is not similar to that of the study of [11] \& [14] found that student love of learning, perseverance, and prudence predicting the student character.

\section{Conclusions}

An empirical model of student character based on character building in teaching learning process is offered by this research. Character building in teaching learning process encouraging student character was not supported. Preparation of teaching learning process, the core of teaching learning process, and the closing of teaching learning process supported character building in teaching learning process. The teacher asking the students to pray before starting the activities in class, the teacher connecting teaching material with developing positive attitude, and the teacher inspecting the neatness of student uniform predicted preparation of teaching learning process. The teacher applying the cooperative learning method in group assignments, the teacher motivating the students to ask bravely, and the teacher paying attention to student attitude in class promoted the core of teaching learning process. The teacher asking the students to pray at the end of the class, the teacher asking the students to greet with the teacher at the end of the class, and the teacher asking the students to do reflection by integrating with character values at the end of the class encouraged the closing of teaching learning process.

\section{Acknowledgements}

Ministry of Research, Technology and Higher Education funded this research through Decentralization Research Grandt.

\section{REFERENCES}

[1] Ministry of National Education. (2014). Curriculum 2013 of elementary schools/madrasah ibtidaiyah. Regulation of Education and Culture Minister, No. 57 in 2014. Retrieved from: http://simpuh.kemenag.go.id/regulasi/permendikbud _57_14.pdf (accessed on July 7, 2018).

[2] Izfanna, D. and Hisyam, M. A. (2012). A comprehensive approach in developing akhlaq", Multicultural Education \& Technology Journal, Vol. 6 No. 2, pp.77-86. Retrieved from: https://www.emeraldinsight.com/doi/full/10.1108/1750497 1211236254 .

[3] Jones, E. N., Ryan, K, \& Bohlin, K. (2012). Character education \& teacher education: how are prospective teachers being prepared to foster good character in students, Action in Teacher Education, Vol. 20 No. 4, pp.11-28. Retrieved from: https://doi.org/10.1080/01626620.1999.10 462931

[4] Ministry of Education and Culture. (2018). Basic Data of Fundamental and Middle Education", Directorate General Fundamental and Middle Education. Retrieved from: http://dapo.dikdasmen.kemdikbud.go.id (accessed May 10, 2018).

[5] Tannir, A., \& Al-Hroub, A. (2013). "Effects of character education on the self-esteem of intellectually able and less able elementary students in Kuwait", International Journal of Specia Education. Vol. 28 No. 2, pp.1-14. Retrieved from: Https:/Www.Researchgate.Net/Publication/305566478_Ef fects_Of_Character_Education_On_The_Self-Esteem_Of Intellectually_Able_And_Less_Able_Elementary_Students _In_Kuwait.

[6] Meidl, C. \& Meidl, T. (2013). Character education in three schools: Catholic, Quaker and public, Education 3-13 International Journal of Primary, Elementary and Early Years Education, Vol. 41 No. 2, pp.178-187. Retrieved from:

[7] Cubukcu, Z. (2012). The effect of hidden curriculum on character education process of primary school student, Education Sciences: Theory \& Practice. Vol. 12 No. 2, pp.1526-1534. Retrieved from: https://files.eric.ed.gov/full text/EJ987859.pdf.

[8] Furkan, N. (2014), The implementation of character education through the school culture in SMA Negeri 1 Dompu and SMA Negeri Kilo Dompu Regency, Journal of Literature, Languages and Linguistics, Vol 3, pp.14-44. Retrieved from: http://www.iiste.org/Journals/index.php/J LLL/article/view/10057/15748

[9] Oktarina, N., Widiyanto, and Soekardi (2015). "Character education evaluation model based on school culture for elementary school", IOSR Journal of Research \& Method in Education, Vol. 5 No. 5, pp.11-14. Retrieved from: http://www.iosrjournals.org/iosr-jrme/papers/Vol-5\%20Iss ue-5/Version-1/C05511114.pdf

[10] Marini, A. (2017). Character building through teaching learning process: Lesson in Indonesia”, Ponte Journal. Vol. 73 No. 5, pp.177-182. Retrieved from: file:///Users/aritama rini/Downloads/Character_Building_Through_Teaching_L ear.pdf.

[11] Wagner, L., \& Ruch, W. (2015). Good character at school: positive classroom behavior mediates the link between character strengths and school achievement", Frontiers in Psychology. Vol. 6, pp.1-13. Retrieved from: https://core.a c.uk/download/pdf/82880959.pdf

[12] Marini, A. (2018). Implementation of character building at 
elementary schools: Cases of Indonesia, Proceeding International Conference on University and Intellectual Culture 2018. Vol. 1 No. 1, pp.60-71. Retrieved from: http://seminars.unj.ac.id/icuic/wp-content/uploads/2018/08 7.-Implementation-of-Character-Building-at-ElementarySchools-Cases-of-Indonesia-by-Arita-Marini-UniversitasNegeri-Jakarta.pdf

[13] Agboola, A., \& Tsai, K. C. (2012). Bring character education into classroom, European Journal of Educational Research. Vol. 1 No. 2, pp.163-170. Retrieved from: https://www.res earchgate.net/publication/283083555_Bring_Character_Ed ucation_into_Classroom.

[14] Ferdiawan, E., \& Putra, W. E. (2013). Esq education for children character building based on philosophy of Javaness in Indonesia, Procedia - Social and Behavioral Sciences. Vol. 106, pp.1096-1102. Retrieved from: www.sciencedire ct.com 